Case Report / Olgu Sunumu

\title{
Incidental diagnosis of extra-gastric gastrointestinal stromal tumor: case report
}

\author{
Tesadüfen saptanan ekstra-gastrik gastrointestinal stromal tümör: \\ olgu sunumu
}

\section{İsmail Şalk ${ }^{1,1}$, Mehmet Atalar'1, Ali Çetin² \\ 'Department of Radiology, and 'Department of Obstetrics and Gynecology, Cumhuriyet University Faculty of Medicine, 58140 Sivas}

\begin{abstract}
The gastrointestinal stromal tumors (GIST) of the gastrointestinal tract may be asymptomatic and discovered incidentally during an endoscopic or barium study or during a computed tomography scan done for another purpose. More often, patients present with nonspecific symptoms such as early satiety, bloating. Surgical resection is the treatment of choice for potentially resectable tumors. In this case report, we present a case with extragastric GIST which incidental diagnosed by during contrast-enhanced multi-detector computed tomography and magnetic resonance imaging examination of abdomen.
\end{abstract}

Keywords: Extra-gastric gastrointestinal stromal tumor, computed tomography, magnetic resonance imaging

Özet

Gastrointestinal traktın gastrointestinal stromal tümörleri (GIST) asemptomatik olabilir ve endoskopik veya baryum çalışmalarında veya başka nedenle yapılan bilgisayarlı tomografi çalışmalarında tesadüfen saptanabilir. Sıklıkla hastalar erken doyma ve şişkinlik gibi nonspesifik belirtiler hissederler. Cerrahi rezeksiyon uygun tümörlerde tercih edilir. $\mathrm{Bu}$ olgu sunumunda karın bölgesinin kontrastlı multidetektör bilgisayarlı tomografi ve manyetik rezonans görüntüleme işlemleri sırasında tesadüfen saptanan bir ekstra-gastrik GIST olgusu ele alınmaktadır.

Anahtar sözcükler: Ekstra-gastrik gastrointestinal stromal tümör, bilgisayarlı tomografi, manyetik rezonans görüntüleme

${ }^{1}$ Corresponding author:

Dr. İsmail Şalk, Radyoloji AD, Cumhuriyet Üniversitesi Tıp Fakültesi, Sivas.

Email: ismailsalk@gmail.com

Salk et al. Extra-gastric gastrointestinal stromal tumor.

This is an open-access article distributed under the terms of the Creative Common Attribution License, which permits unrestricted use, distribution, and reproduction in any medium, provided the original author(s) and source are credited.

This article may be cited as: Salk I, Atalar M, Cetin A. Incidental diagnosis of extra-gastric gastrointestinal stromal tumor: case report. Basic Clin Sci 2013; 2: 128-131. Available from: www.bcsciences.com. 


\section{Introduction}

Gastrointestinal stromal tumors (GISTs) is an important group of mesenchymal neoplasms affecting the gastrointestinal tract. They typically present as subepithelial neoplasms that are most often located in the stomach and proximal small intestine, but can occur in any portion of the gastrointestinal tract [1,2]. During laparoscopic bariatric surgery, the incidence of incidental pathology found was about $2 \%$, and gastric gastrointestinal stromal tumors have been found in $0.8 \%$ of patients, constituting a rather uncommon finding [3]. Surgical resection is the treatment of choice for potentially resectable tumors.

In this report, we present a case with extra-gastric gastrointestinal stromal tumor which incidental diagnosed by during contrast-enhanced multi-detector computed tomography (MDCT) and magnetic resonance imaging (MRI) examination of abdomen.

\section{Case}

A 64-year-old woman was admitted to our hospital with a complaint of vague pain around the umbilicus for a period of six-months. There was no history of prior trauma or any abdominal surgery or procedure. Physical examination revealed slight tenderness around the umbilicus. Other physical examinations were unremarkable. All routine laboratory values and blood counts were within normal limits. Endoscopic examination of the gastrointestinal tract showed that there was extrinsic compression of a possible abdominal mass on the gastric wall.

For the differential diagnosis of abdominal pain, computed tomography (CT) was performed with a 16-slice MDCT (Brilliance 16, Philips Medical Systems, Amsterdam, Holland) scanner, including sagittal and coronal reconstructed images. The patient received non-ionic intravenous contrast media. Than MRI scan was performed for the differential diagnosis of abdominal mass detected by CT.

Abdominal imaging revealed a well-delineated homogeneous mass ( 37 × 22 x $26 \mathrm{~mm}$ ). The mass enhanced intensely and homogenously after administration of contrast material. The mass was found between the gastric wall and the left lobe of liver. The mass was diagnosed as an extra gastric lesion (Figure 1).

Surgical exploration was confirmed the diagnosis of extra gastric mass. GIST was diagnosed with histopathologic examination. The patient had an uneventful recovery and at the follow-up examination, there was no complaint of patient related to the GIST.

\section{Discussion}

Establishing a preoperative diagnosis of gastrointestinal stromal tumors (GISTs) is difficult. Contrast-enhanced CT is the imaging method of choice to determine the type of an abdominal mass, evaluate its extent, and the presence or absence of metastatic disease. IV contrast should be administered to define the border and content of the mass. MRI adds information about the borders and solid structure of the mass and is confirmed the 
enhancement seen with CT. In the large tumors, the findings of abdominal imaging may be very complex due to necrosis, hemorrhage, or degenerating components [4, 2].

While there are studies about the severity of mesenchymal tumors by various criteria for malignancy, such as tumor size, cellularity, mitotic index, and DNA content [5], submucosal tumors of the stomach including GISTs have been classified into four growth patterns according to a previous report [6], namely, intragastric, intraluminal, extra gastric, and mixed patterns. In our case, there was a GIST mass of the stomach showing extra gastric growth [5-7].

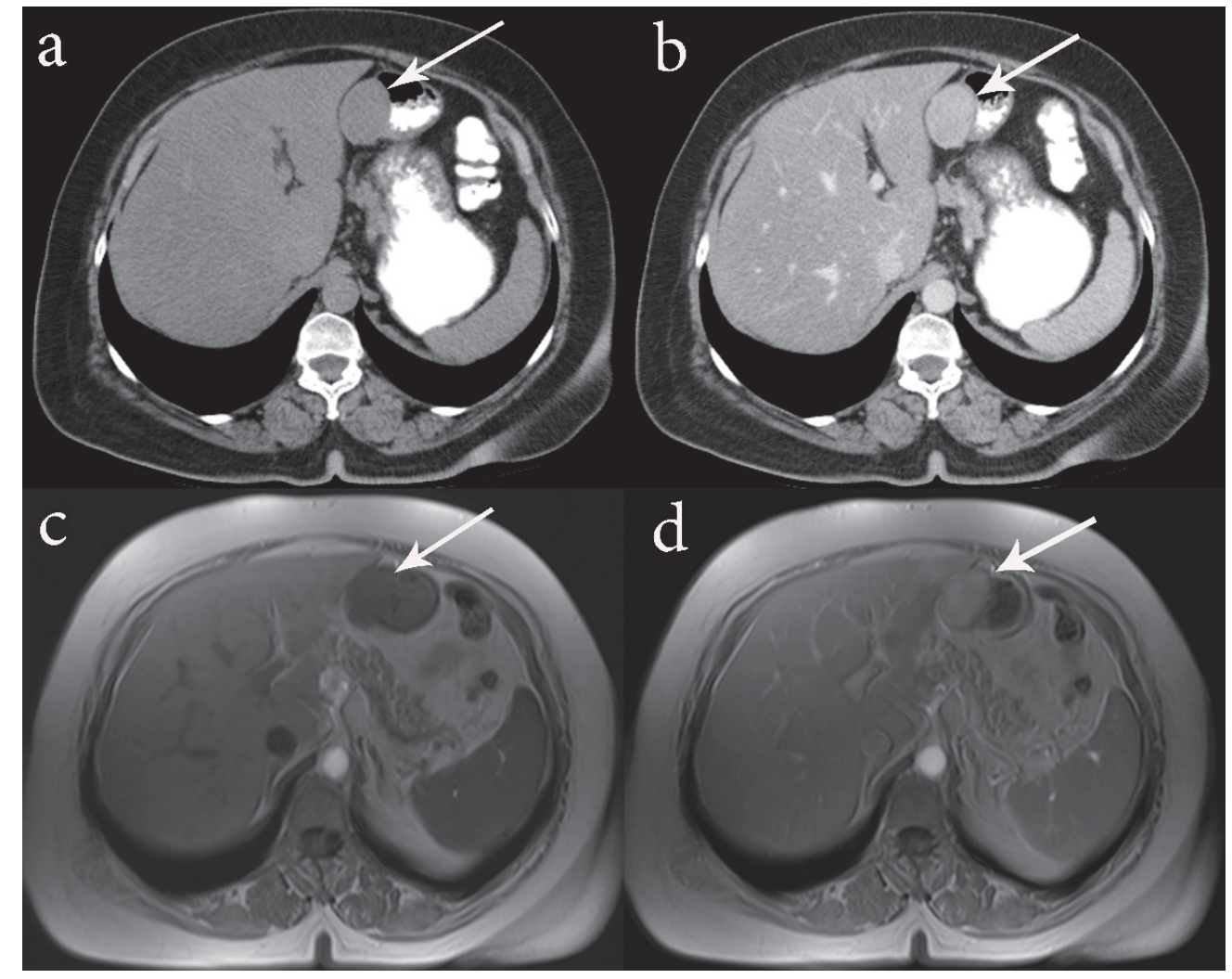

Figure 1. A well-delineated homogeneous mass between the gastric wall and the left lobe of liver. Findings of computed tomography (a and b [with contrast]) and magnetic resonance imaging (c and $\mathbf{d}$ [with contrast]).

We reported on a unique and clinically and surgically significant case of GIST. Abdominal imaging with CT and MRI can provide valuable information for surgical management. The awareness about the variations of abdominal tumors is of great importance for surgeons in order to reduce complications during abdominal surgeries, as well as for radiologists for precise interpretation of abdominal CT and MRI.

This is an open-access article distributed under the terms of the Creative Common Attribution License, which permits unrestricted use, distribution, and reproduction in any medium, provided the original author(s) and source are credited.

This article may be cited as: Salk I, Atalar M, Cetin A. Incidental diagnosis of extra-gastric gastrointestinal stromal tumor: case report. Basic Clin Sci 2013; 2: 128-131. Available from: www.bcsciences.com. 


\section{References}

1. Basir N, Yaakub AB, Kafeel G, Telisinghe PU, Tan KK, Sharif F, Chong VH. Gastroduodenal intussusception as a first manifestation of gastric gastrointestinal stromal tumor. Turk J Gastroenterol. 2012 Apr;23(2):185-6.

2. Beltran MA, Pujado B, Méndez PE, Gonzáles FJ, Margulis DI, Contreras MA, Cruces KS. Gastric gastrointestinal stromal tumor (GIST) incidentally found and resected during laparoscopic sleeve gastrectomy. Obes Surg. 2010 Mar;20(3):393-6.

3. Kimura H, Yoshida T, Kinoshita S, Takahashi I. Pedunculated giant gastrointestinal stromal tumor of the stomach showing extragastric growth: report of a case. Surg Today. 2004;34(2):159-62.

4. Asija AP, Mejia AV, Prestipino A, Pillai MV. Gastrointestinal Stromal Tumors: A Review. Am J Ther. 2013 Aug 12. [Epub ahead of print].

5. Demetri GD, Morgan J, Raut CP. Epidemiology, classification, clinical presentation, prognostic features, and diagnostic work-up of gastrointestinal mesenchymal neoplasms including GIST. In: UpToDate, Basow, DS (Ed), UpToDate, Waltham, MA, 2013 .

6. Kimura H, Yonemura Y, Kadoya N, Kosaka T, Miwa K, Miyazaki I, Sawa T, Yoshimitsu S, Nishida Y, Kamata T, et al. Prognostic factors in primary gastrointestinal leiomyosarcoma: a retrospective study. World J Surg. 1991 Nov-Dec;15(6):771-6; discussion 776-7.

7. Skandalakis JE, Gray SW, Shepard D. Smooth muscle tumors of the stomach. Int Abstr Surg. 1960 Mar;110:209-26. 